\title{
EIA- A Teacher Education Project in Bangladesh: An Analysis from Diversified Perspectives
}

\author{
Abdul Karim \\ Graduate Research Student, School of Educational Studies, Universiti Sains Malaysia, \\ Malaysia,khasan13aiub@gmail.com \\ Abdul Rashid Mohamed \\ Prof., School of Educational Studies, Universiti Sains Malaysia, Malaysia, \\ richsesusm@gmail.com

\section{Mohammad Mosiur Rahman} \\ Graduate Research Student, School of Languages, Literacies and Translation, Universiti \\ Sains Malaysia, Malaysia, mosiurbhai@gmail.com
}

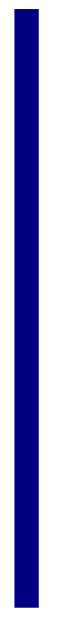

\begin{abstract}
English in Action (EIA) is an ongoing teacher education project which places mobile technology at the centre of its action. Most of the studies carried out focused on the changes EIA brought in teachers' classroom actions. Along with this, they also explored the classroom to observe whether the input given during training program is implemented in real life. No study has been conducted that compares and contrasts the components of mobile learning in general and the components EIA is using. This study, particularly, drew a comparative analysis between the mobile learning and EIA initiated mobile learning to reveal the extent it matched or mismatched to the components of mobile learning. It also scrutinized teachers' behavior in the classroom after participating in EIA. It also penetrated to find the contents to be reviewed. Qualitative method was used to conduct this study. The result revealed that the components of EIA match to the mobile learning ones to the extent that EIA entails those suiting the context. Few elements were seemed absent as they are less suitable in such context. Besides, teachers were found bringing changes in their classrooms. The introduction of action research and reflective teaching were suggested to add to EIA's program.
\end{abstract}

Keywords: EIA, EFL, teacher education, mobile learning, critical discussion

\section{INTRODUCTION}

Teacher education plays a vital role in the development of both the teacher quality and students learning. Therefore, for most of the countries, teacher education is placed at the centre of national education policies due to its global significance (Mahruf, Shohel \&

Citation: Karim, A., Mohamed, A. R., \& Rahman, M. M. (2017). EIA- A Teacher Education Project in Bangladesh: An Analysis from Diversified Perspectives. International Journal of Instruction, 10(4), 51-66. https://doi.org/10.12973/iji.2017.1044a 
Banks, 2012). Typically, teacher education and training entail the issues and trends relating to the implementation of theory to the practice (Morris \& J, 2000). They identified school as the best setting for Teacher Professional Development (TPD) to take place. Banks, Moon and Wolfenden (2009) suggest the integration of technology in teacher training programs. However, in Bangladesh, teacher development programs are conducted removing teachers from their workplace (Mahruf, Shohel \& Kirkwood, 2012). As a result, the goal of the CLT curriculum is to develop students' communicative ability, which has not been achieved (Chowdhury and Ha 2008; Hamid and Baldauf 2008; Hamid, Sussex \& Khan 2009). To bridge the gap, Shohel and Power (2010) recommended the school-based professional support for Bangladeshi teachers in developing their own English language and teaching skills. Therefore, English in Action (EIA) introduces teacher development program in schools using mobile phone as the core tool to impart training. The previous studies aimed at understanding the impact of EIA's training on teachers' classroom practice. However, this paper has a meticulous intention to explore EIA from various perspectives which are discussed in the following section.

\section{A vignette of mobile technology}

Some key issues regarding mobile technology must be delineated to further the plausible discussion. Thus, the following pertinent literature review is done.

\section{Mobile Technology in Teacher Education Program}

Portable and networked technology device, mobile, has been an inevitable part of human life for the last twenty years (Baran, 2014). The ease and availability make it 'musthave' among the various age groups (Newhouse, Williams, \& Pearson, 2006). Applying mobile phone to the teacher training programs, nowadays, the repertoires for teaching can be attained faster than adopting the conventional tools. Shrestha (2012) expounds that leaving the obsolete teacher training strategies, mobile technologies offer flexible learning in terms of getting access to the resources for language learning. Beckmann (2010) considered them as breaking the shackles between teacher-student relationships. There are some scattered studies conducted on the use of mobile technology in teacher training program. Ekanayake and Wishart (2015) argued that few number of studies have been conducted on mobile learning in teacher support and training programs. Even in teacher education, as Kearney and Maher (2013) state, theory on mobile learning can hardly be found. Nevertheless, it is necessitated to equip teachers cognizant about the accentuation of mobile technologies and their meaningful adaptation to the classes (Schuck, Aubusson, Kearney, \& Burden, 2013). The dearth of relevant theory, therefore, accelerates bewildered perception regarding the use of mobile phone in teacher training programs. In what follows, a conceptual framework will be developed based on the definition generated from scholars working on mobile learning.

\section{Features of Mobile Learning}

The features of mobile technology such as mobility, access, immediacy, situation, ubiquity, convenience and context are underscored in the mobile learning (Sharples et al., 2009; Parsons \& Ryu, 2006; Kynäslahti, 2003; Cheon, Lee, Crooks, \& Song, 2012; 
Kukulska-Hulme et al., 2009; Kearney, Schuck, Burden, \& Aubusson, 2012). Thus, this definition refers to the feasibility of mobile learning since this facilitates lessons at anytime and anywhere someone is intending to learn. The mobility, according to Sharples et al. (2009), is its rolling in physical, conceptual, and social settings. The most significant purpose mobile learning serves is that learning can take place in independent, formal, or socialized settings (Frohberg et al., 2009). Overall, the aforementioned features facilitated by mobile learning are homogenous. Kearney et al. (2012), in contrast, reveal three heterogeneous purposes of m-learning that it is authentic, collaborative and individualistic. Kearney and Maher (2013) situate pedagogy as the core of mobile learning with a view to scrutinize the benefits to support learning. The phenomenal 'mobagogy', termed by Schuck et al. (2013), comprises underlying ideology of a professional learning community (PLC) and a community of practice $(\mathrm{CoP})$ to "capture dual interests of the community in mobile technologies and pedagogy" (p. 4). Below is a framework drawn on mobile learning underpinned by the aforementioned definitions. The definitions have diversity. The framework is an accumulated reflection on these. Generally, what mobile learning subsumes typically is illustrated here.

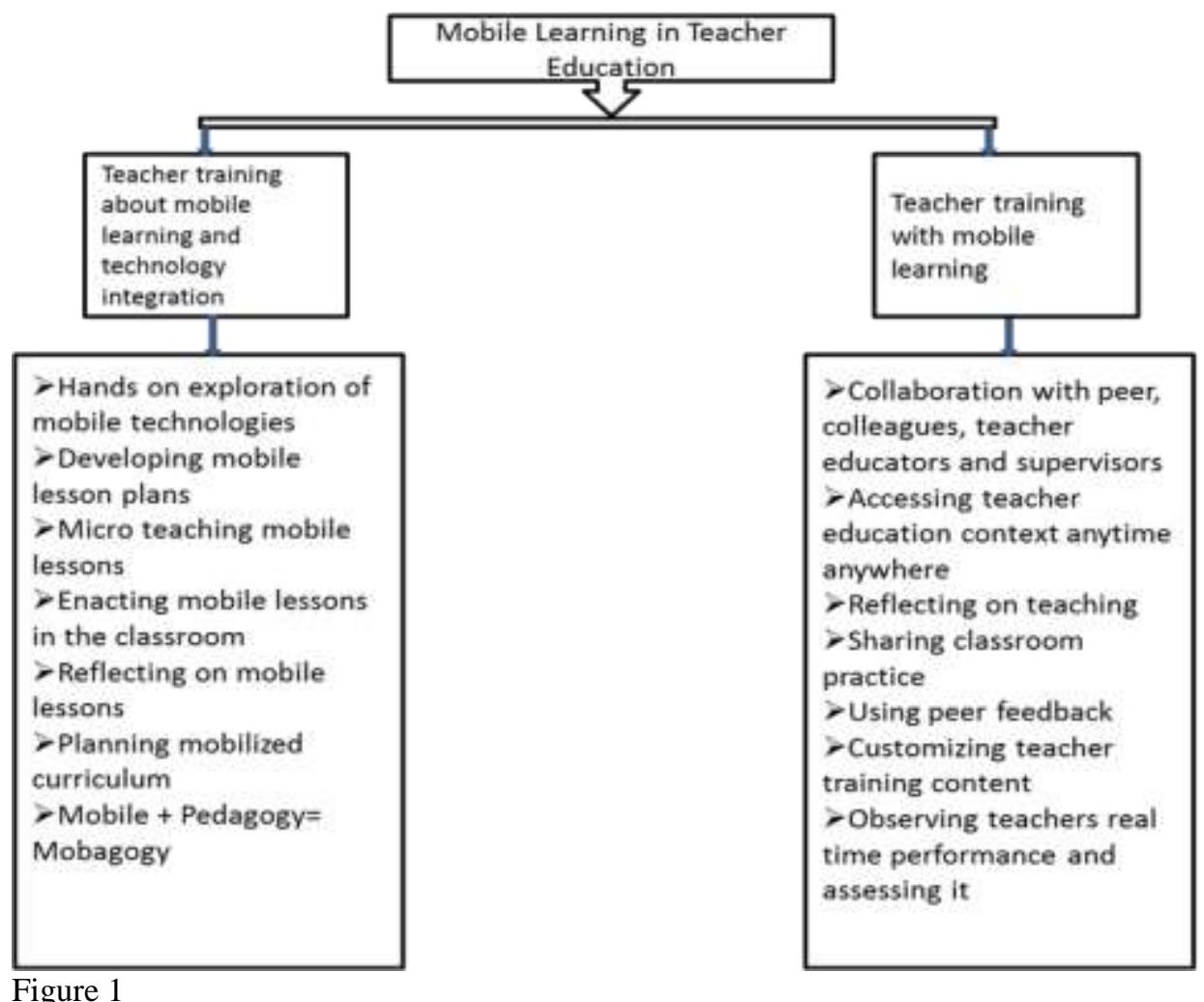

Figure 1

Framework for mobile learning in Teacher Education 


\section{Assessment Procedure}

Baran (2014) promulgates that mobile phones, additionally, let both pre-service and inservice teachers assess their peer's performance in conjunction with their own. For this to be effective, Mobile Assessment Participation System (MAPS), developed by Chen (2010), yields both synchronous and asynchronous assessment of pre-service teachers' self, peer, and group performances meaning that in a teacher training program, sometimes, immediate constructive feedback are made during the session and sometimes, it is done after the session ends. MAPS can also be introduced in the inservice teacher training program as it gravitates the effectiveness of such program. Because the comments on the individual performance are delivered with spontaneity and courage, the teachers have the instant pedagogic improvements.

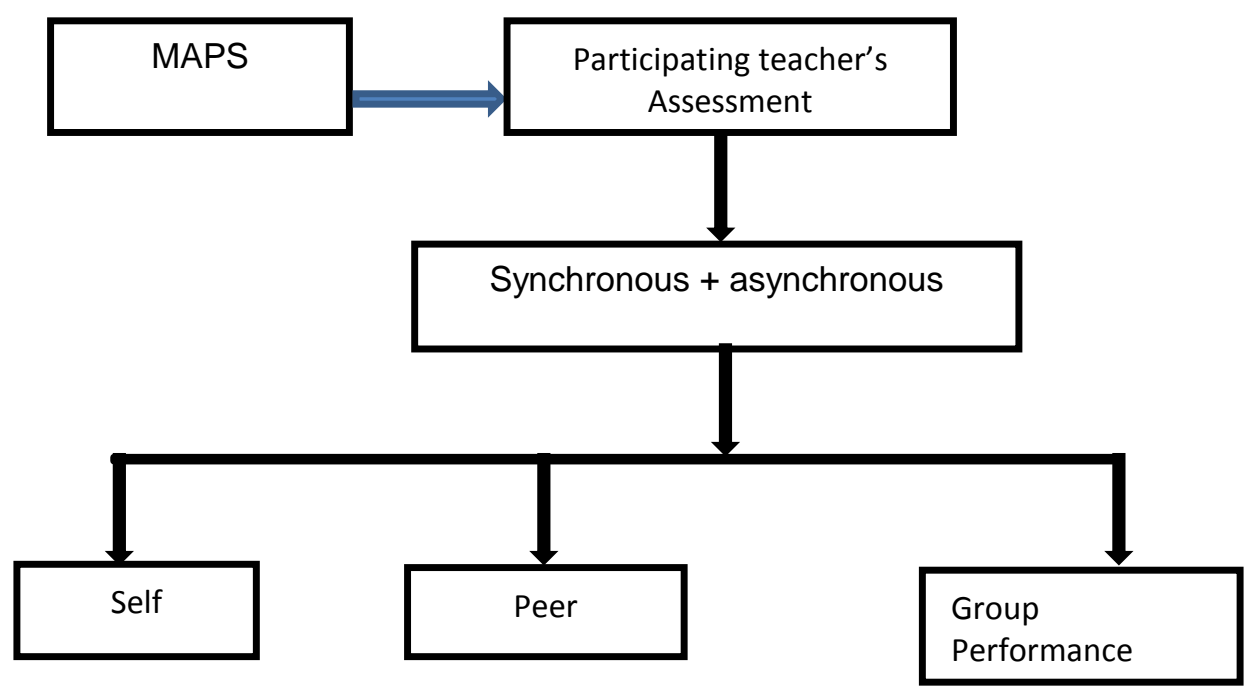

Figure 2

Mobile assessment participation system (Chen, 2010)

\section{Mobile Technology in Bangladeshi ELT}

Number of mobile technology users in Bangladesh has been soaring for the last ten years (Shrestha, 2012). Along with the certain purposes - calling, texting and so on, the mobile phone is providing the users with learning opportunities even when they are on the move (Kukulska-Hulme, 2009). The use of mobile phone for teaching and learning in developing countries is on the rise (e.g., Shrestha, 2011). Being one of them, Bangladesh has also been experiencing the adoption of mobile technology in English teacher training program. Here, English Language Teaching (ELT) community is utilizing the potentiality of this to facilitate English language teachers' professional development (PD) (Shrestha, 2012), and EIA shares, particularly, the responsibility of implementing the programme. It also generates opportunities to the learners of English language. 


\section{The Emergence of EIA in Bangladesh}

Placed English language as the core requisite for rapid economic growth, following other developing nations (Littlewood, 2007), Bangladesh also introduced training program for English language teachers to develop a didactic approach among the teachers to produce citizens equipped with a good command in English (Shrestha, 2012). Several project-based training programs for English teachers, belong to both primary and secondary level, have been arranged having fund from organizations, such as, Department for International Development (DFID) and world bank, with a view to attain the skills of this language. Deplorably, as Shrestha (2012) divulges, the achievement is below the level of expectation. The pressing reason behind less achievement is the dissatisfactory adaptation of the methodology - CLT - in the classroom. Study conducted by Teaching Quality Improvement (TQI) has revealed more detrimental issue that teachers tend to follow the traditional grammar-translation method (TQI-SEP, 2007). Such finding is endorsed by other native researchers (e.g., Chowdhury \& Ha, 2008; Hamid \& Baldauf, 2008).

The donor-funded projects for promoting the teachers' skills though failed earlier, but there was no question about their potentiality (Hamid, 2010). Question raised triggered on whether the projects fulfil the commitments and equip the teachers for what they were designed, he added. It is worth mentioning that teachers have degree from universities but a degree in English does not prepare people to teach others how to communicate fluently in English (English in Action, 2010, pp. i-ii).

In the teacher-oriented English lessons, book, chalk, duster and blackboard were the tools used in the classroom (EIA, 2009b). The study also revealed that classrooms are mostly Bengali dominated. Hardly did the lessons facilitate students' talk using the target language. The study got concluded stating that teachers volitionally followed the conventional grammar-translation method, and they are found reluctant to adopt communicative approach. Considering the aforementioned results, EIA started to train teachers by adapting mobile technology and classroom setting which is unquestionably considered as a new thought since previous training programs excluded pedagogy.

\section{English in Action}

Aiming at improving skills in English language to serve the socio-economic purposes of 25 million people in Bangladesh, EIA, a nine-year project, is developed (Shrestha, 2012). The project costs $£ 50$ million. The project has been started having requested by the government of Bangladesh and funded by Department for International Development (DFID), UK. The project aims at developing activities and materials, using mobile technology, for the teacher in both primary (Grade 1-5) and secondary (Grade 6-10) level to foster the repertoires for teaching. That is how the project reaches millions. This is a consortium of national and international partners, and run by BMB Mott McDonald, The Open University (UK) and The British Broadcast Corporation (BBC) Media Action Group. EIA is innovative in a sense that it integrates mobile technologies, such as, iPods and mobile phones as tools for supporting and designing classroom activities of English language. 


\begin{abstract}
Aim of EIA
The aim of EIA is to facilitate rigorous changes by introducing modified and feasible English teaching and learning practices. That is the way to achieve better communicative ability. Walsh and Power (2011) added, for the socio-economic development of the citizens, it aims to provide people with English language to make them communicate effectively in a global platform. By the end of 2017, EIA will train 51,000 Bangladeshi teachers under the ICT-enhanced teacher professional development (Ali \& Walker, 2014).

\section{Components of EIA}

Centered on the base of the program, mobile phone, named as 'trainer in your pocket' (Walsh et al., 2013), serves the operational purposes. Alongside, it recruits twelve Bangladeshi teacher development coordinators (TDCs) equipped with extensive English Communicative Language Teaching and pedagogical training. Two of whom, from the beginning, are assigned to develop materials and resources, and they have already produced 355 audio tapes (primarily dialogues, then songs) for the primary sections (Grade 1-5). The remaining ones function as teacher facilitators (TFs) in the field training. Meticulously they work in pairs to provide training for the teachers in their Upazilla (Sub- District).
\end{abstract}

\title{
How EIA Functions?
}

Mahruf, Sohel and Banks (2012) mentioned that by intervening carefully prepared segments of information and communication technology (ICT) in the teachers' professional development (TPD), EIA triggers on changing the conventional act of the teachers in the classroom. A school-based support model has been designed. It involves media players (the iPod) for the English language teachers, preloaded with video and audio language learning resources, along with battery-powered speakers for use in the classroom, and a teacher guide covering 12 modules about CLT, each focused on a particular activity designed to be taught in a secondary classroom. Demonstrating the activity, exploring principles underpinning the activity and encouraging the teachers to adopt and adapt these in the classroom are the fundamental concerns of the modules. In this school-based TPD model, teachers are provided with orientation workshop, a teacher guide, a multimedia player. Additionally, they are given opportunity to participate in cluster meetings. EIA staffs also visit the school and generate constructive feedback and required assistance.

\section{Teacher Support Model}

The fundamental role of EIA is to provide teachers with school-based support, meaning that the training program is held in the school setting (Shrestha, 2012). This is popularly known as School-Based Professional Development (SBPD). Ostensibly, all the activities are accomplished in the school. The indispensable tool in this program is the iPod, which teachers hold in their pocket so that they can get access to this whenever they need. Teachers are paired up with each other from same school to support and promote learning opportunities. Seemingly evident is it that such learning does not necessarily 
require educators or trainer from outside as other programs do constantly, she mentioned. This is one form of support for the teachers. Beside this, appointing Teacher Facilitator (TF) who is generally a practicing teacher in the Upazilla (Sub-district, a smaller administrative region than district), this program mentors the participating teachers. In front of TF, every teacher performs his lesson every month, and TF delivers constructive feedback to further their development.

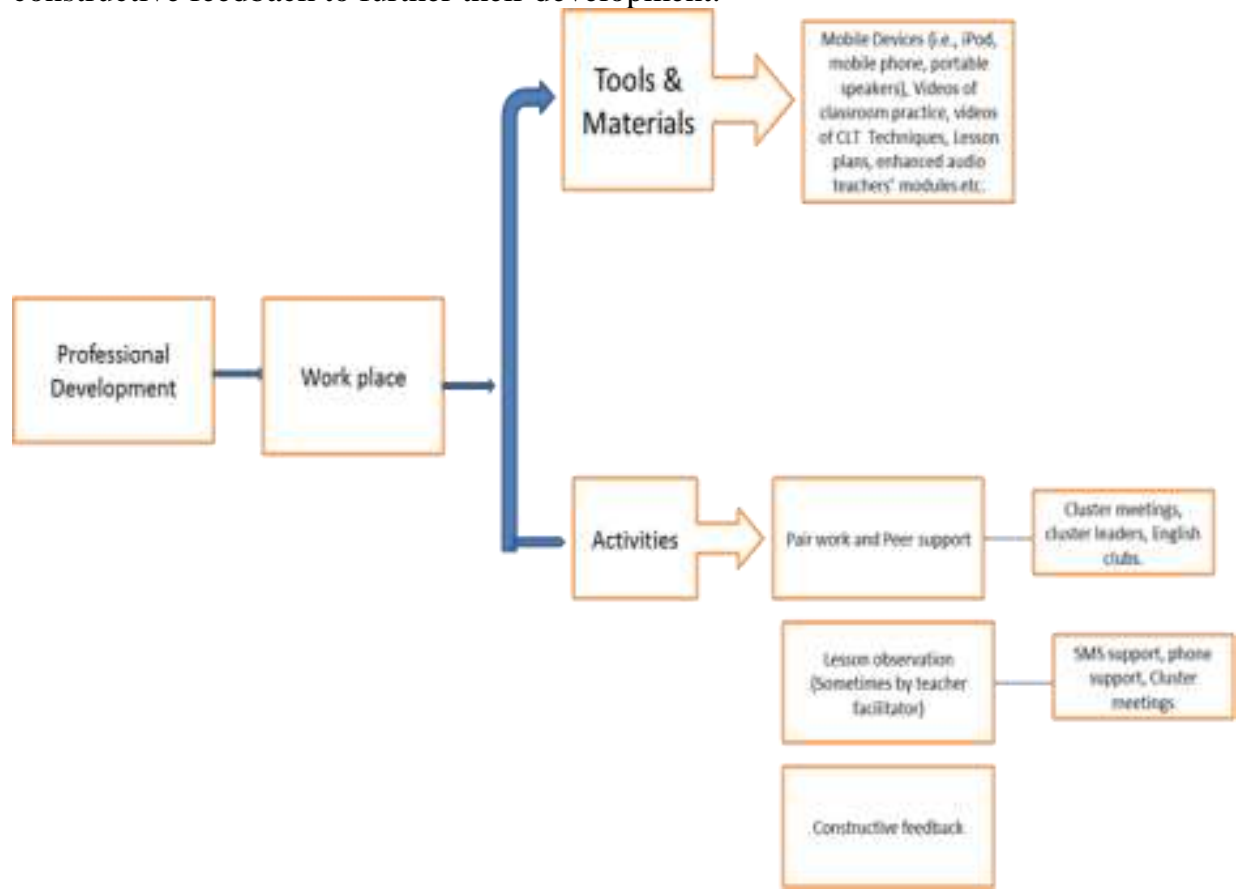

Figure 3

EIA's Teacher Support Model

\section{Aim of the article}

This paper is set out with numerous aims to be accomplished. These are as follows:

* To scrutinize the outcome of EIA's teacher training project;

* To reveal the extent to which the components of EIA' school-based professional development for the teachers match or mismatch to the mobile learning framework;

* To figure out the aspects of this program to be reviewed and suggest the areas of opportunity to be considered.

The previously conducted studies solely focus on the change of teachers' classroom behavior after being trained from EIA project. There is a significant gap exists in the previous studies regarding the examination of the components used in EIA. Therefore, it addresses the comparison between EIA mobile learning framework and that of mobile learning in teacher education. 


\begin{abstract}
METHOD
Present study has adopted secondary data analysis as the instrument of data collection. A systematic search was conducted in SCOPUS using the keywords like: EIA; Mobile Learning technologies; School based professional development; CLT in Bangladesh etc. To understand the phenomenon of English teaching after EIA being stated, this paper collected data from the resources published between 2008 and 2016. The articles that was reviewed in the process have been mentioned in the reference. Mostly, they intended to reveal the outcome of EIA project in Bangladesh through the practice of CLT in the classroom and presented the theoretical framework for mobile learning. Secondary data analysis has been growing the popularity and hosts of researchers have been concentrated on secondary data analysis as a research methodology e.g. Karim \& Rahman (2016); Rahman \& Pandian (2016), because of their significant insights.

The analysis of data was conducted thematically. The themes were emerged from the data and were related to the variables of the study that were framed in the objectives, since the article were chosen based on them. Under each theme or heading, further subthemes emerged. For the natural relationship between the objectives of the study and research findings, the findings were presented under the heading of each objective. The exploratory nature of the objectives of study ensured any probable results, without making early hypothesis of outcomes. That was aided the analysis to be more reliable and valid, by excluding the tentative biasness for the particular result method helps the researcher find out with the pertinent information to achieve the aims of this paper.
\end{abstract}

\title{
FINDINGS AND DISCUSSION
}

\section{Research Objective 1:}

The first objective of this study was to scrutinize the outcome of EIA's teacher training project. After reviewing the literature related the phenomenon following themes have been emerged.

\section{Technology has made teachers' life easy}

With teachers receiving training under the aegis of EIA, are generally facilitated with substantial opportunities. For instance, Maruf, Shohel and Kirkwood (2012) draw a vignette regarding the benefits EIA generates for the teachers. It is seen that the effect of contents provided for the teacher on iPod is remarkable. Improvements found in both individual and professional level. For example, getting access to the resources, teachers can correct their language skills, such as, pronunciation. Most appealing part for the teachers is the chance to listen to the pre-stored audio materials at their convenient time. In no way, do these trivialize teachers. Instead, teachers have now the freedom to use the resources in various ways depending on the suitability. Besides, recited poems in the audio section provided chance for them to follow and learn by hearing them.

\section{Technology has impacted teachers' classroom practice}

These achievements result in noticeable changes in teachers' classroom practices. Shaheen, Walsh, Power and Burton (2013) found teachers' conducting interactive and 
communicative English classes. Question and answer session takes $27 \%$ of the class time. Active participation of students in classroom discussion is highly encouraged by the teachers while previously, teacher led classes by solely reading and presenting from the textbook. Pair work and group work, the core of CLT methodology, are also introduced. Regarding proficiency in English, according to the assessment done by Trinity College London, EIA trained teachers in both primary and secondary - 230 primary and 87 secondary - scored high, which becomes the endorsement for primary teachers to teach grade 3 students and secondary ones to teach grade 6 pupils (Walsh et al., 2013). Rahman and Akter (2015) elicit that for the majority, teachers perceive audio resources as offering tremendous benefits in their classes. Since there are three quarters in a year and Bangladeshi school syllabus is compartmentalized depending on this, in the first two quarters, teachers find such files more effective, and thus, use them in the classroom happily. However, they figure out the reluctance of the teacher to use these in the final quarter as this part entails the revision of whole syllabus.

\section{Student centred classroom}

Teachers were found to be less authoritative with the technological innovation, which ultimately leads to a student cantered classroom. As Walsh et al. (2013) observe, Chorus and discussion comprise $53 \%$ and $38 \%$ of class time respectively. In the primary level, student talking time (STT) is rose by $24 \%$, obviously using the target language. Similarly, Li, McCormick, Power, Burton, Siddique and Rahman (2015) found that students talk in English during the class for considerable amount of time (94\%). These studies are significant because such classes set out for developing the communicative ability of the students in English, which Nunan (1991) considered as the ultimate aim of ELT. They also found that teacher talking time (TTT) also decreased by $50 \%$ of total lesson time. Comparing to the classes before teachers being under EIA training, there is a superfluity in using target language, and teachers are seemed to conduct classes using this, which is accountable for $81 \%$ of TTT. Such outcome is portrayed in the secondary level as well. TTT becomes reduced, however, when they talk, they use English. Students' participation also increases as in the primary level.

\section{Research objective: 2}

The second research objective for the study was to reveal the extent to which the components of EIA' school-based professional development for the teachers match or mismatch to the mobile learning framework. The findings were found to be divergent between similarities and differences. They are discussed under two separate themes below.

\section{Similarities between EIA'SBPD and the mobile learning framework}

Mobile learning in teacher education, as seen in Figure 1, is divided into two partsTeacher training about mobile learning and teacher training with mobile learning. EIA, in Bangladesh, has no such distinction. Yet, in most part, it covers the contents belong to two branches. Firstly, when teachers are given input about mobile learning, this generally entails the enhancement of their expertise on mobile technology, and secondly, 
the activities related to the evaluation of the project by assessing the change in the practice of the teachers.

EIA involves phone support and SMS support in its program. Developing mobile lesson plans is a part of teacher education in mobile learning. In the conceptual framework, the collaboration with teacher educators and supervisors is mentioned. However, teacher facilitator is employed to mentor the participating teacher in EIA. They observe the teachers' performance, assess it based on the input delivered during the session and make constructive feedback, a crucial part of mobile learning. Mostly, such performance is observed in EIA by the peers. Therefore, mobile lessons are often reflected in EIA. Basically, the training is provided for the teachers based on such lessons. Teachers, after having the input, are expected to simulate the lessons in their classroom practice. This refers to the adaptation of the learned contents in the real practice. Hence, the customization of teacher training content prevails in EIA.

Likewise, the mobile learning framework that evaluates the programme through the performance of the teachers, EIA has also adopted its own Quality Assurance (QA) system built to assure the remedy of any problems, customization and refinements as the project progresses. Besides that, summative and formative evaluations are done to evaluate the result of a particular element of the program. So, this is the assessment of different components used in the program which are mostly related with mobile learning framework.

\section{Differences between EIA' SBPD and the mobile learning framework}

In EIA, teachers are not having training on preparing such lessons plan. As per its functions, it is found that it provides teachers iPod with preloaded video and audio language learning resources. Thus, teachers do not need to prepare materials by themselves. Besides, teachers are provided with a teacher guide containing 12 modules about CLT, each of which covers different activity developed to teach in a secondary classroom. Micro teaching mobile learning is absent in EIA in a sense that it generally involves the planning, teaching, observation, re-planning, re-teaching and reobservation. The 12 modules about CLT deployed by EIA is the prepared class-planning for the teachers to follow. Therefore, teacher initiated such planning which micro teaching refers to is not practiced here. Although teaching practice and observation take place in EIA, observation does not necessarily require permanent educators or trainer from outside (Shrestha, 2012).

In the evaluation process, despite their similarities, EIA' SBPD and the mobile learning framework, do share some differences. In contrast, EIA's evaluation, either immediate or after the session, is concern about the elements. Teachers in EIA are not assessed under a predetermined framework as that of MAPS (figure 2). Rather, as mentioned earlier, assessment is done based on the performance of the teachers in front of peers or sometimes teacher facilitator. Besides, McCormick, Eyres and Burton (2012) expound the diagnostic test that the participating teachers are undergone through is based on the Trinity College Graded Examinations in Spoken English (GESE). It assesses their speaking ability using English language. The assessment 'replicates real-life exchanges 
in which the candidate and the examiner pass on information, share ideas and opinions and debate topical issues' (Trinity College London 2009: 6).

\section{Issues to Be Considered}

EIA has its own policy assumption, and containing this, it is running (Ali \& Walker. 2014). They argue that having policy in a project is not enough because the policy has to comply with the socio-cultural and contextual aspects of Bangladesh. Thus, there is no denying fact that EIA's policy, to some extent, mismatches to this EFL context, they claimed. Seargeant and Erling (2011) exemplify that the assumptions of EIA include 'English as a global language ', 'English and economic value, 'English as a language for education', and 'English as a language for technology'. Ali and Walker (2014), therefore, question on the adaptation of these assumptions to national ELT curriculum. The goal of the Bangladesh national ELT curriculum is the attainment of communicative skills of the learners (Ali, 2010b). But, EIA is yet to clarify its actions to equip both the learners and teachers to achieve the goal of the curriculum.

\section{Research Objective: 3}

The third research objective of the article was to figure out the aspects of this program to be reviewed and suggest the areas of opportunity to be considered. To address this objective, the existing literature was reviewed to find out the challenges and recordation that they have made.

\section{Challenges}

Electricity in Bangladesh is reported as unreliable and 30\% of the population is yet to get electricity (UNESCO, 2008). Thus, Mahruf et al. (2012) claimed the hindrances involved in the use of technology in education. Walsh et al. (2013) also identified the same problem. Teachers are seemed to experience problem with charging the iPod and speaker due to resistance in electricity supply. In conjunction with this, teachers found it tedious to recharge these two devices. Besides, teachers face difficulty in carrying the devices from home to the school because of their heavy weight. Moreover, the high cost of iPod Nano and touch is another considerable problem.

\section{RECOMMENDATION}

The teacher should be provided training concentrating on the third quarter to achieve the prowess so that they can handle the pressure before final examination (Rahman \& Akter, 2015). Besides, EIA, to be more flourished and effective, should introduce "reflective teaching" beside other concurrent components in the training program. Being schoolbased, it has convenience to suppose teachers to exercise reflective teaching. Lee (2007) exemplified Hong Kong where critical thinking would have been enhanced by involving in reflection through dialogue or response journals. For newly appointed ESL teachers, Farrell (2016) recommends the involvement in peer reflection as it helps them to achieve better understanding of the situational shocks experienced initially. Therefore, these evidences make the importance of reflective journal conspicuous. In addition, classroom equipped with speakers and consistent power supply can solve the problems raised from carrying these. 


\section{CONCLUSION}

With many components under this, mobile learning becomes an umbrella. EIA adopts the contents that address the demand of the context. Adapting the mobile technology in English teacher training program, it tries to improve the teachers in both personal and professional level. Of particular development is the change in teachers' classroom behavior that leads conventional classes to that of student-cantered. However, some mismatches between the policy of EIA and national curriculum are identified. It is, therefore, important to provide with satisfactory reconsideration on this issue because, the necessity for teacher development program of being compliant with the national education policy cannot be overlooked.

\section{REFERENCES}

Ali, M., \& Walker, A. L. (2014). 'Bogged down'ELT in Bangladesh: Problems and policy. English Today, 30(2), 33-38.

Ali, M. M. (2010b). 'Revisiting the English Language Teaching (ELT) curriculum design: How appropriate is Bangladesh higher secondary level national ELT curriculum as a learner-centred one?' IIUC Studies, 7(1), 283-96.

Banks, F., Moon, B., \& Wolfenden, F. (2009). New modes of communication technologies and the reform of open and distance learning programmes: A response to the global crisis in teacher education and training.

Baran, E. (2014). A review of research on mobile learning in teacher education. Educational Technology \& Society, 17(4), 17-32.

Beckmann, E. A. (2010). Learners on the move: mobile modalities in development studies. Distance Education, 31(2), 159-173.

Boissiere, M. (2004). Determinants of primary education outcomes in developing countries. Determinants of Primary Education Outcomes in Developing Countries.

Cabaroglu, N. (2014). Professional development through action research: Impact on self-efficacy. System, 44, 79-88.

Cheon, J., Lee, S., Crooks, S. M., \& Song, J. (2012). An investigation of mobile learning readiness in higher education based on the theory of planned behavior. Computers \& Education, 59(3), 1054-1064.

Chen, C. H. (2010). The implementation and evaluation of a mobile self-and peerassessment system. Computers \& Education, 55(1), 229-236.

Chowdhury, R., \& Le Ha, P. (2008). Reflecting on Western TESOL training and communicative language teaching: Bangladeshi teachers' voices. Asia Pacific Journal of Education, 28(3), 305-316.

Dembele, M. (2005). Breaking the mold: Teacher development for pedagogical renewal. The challenge of learning: improving the quality of basic education in sub-Saharan Africa, 167-194. 
English in Action. (2010). Baseline study 5: An audit of a range of English language teacher training and education provision. Retrieved June 30, 2010, from http://www.eiabd.com/eia/index.php/publications/baseline-studies

English in Action. (2011). The classroom practices of primary and secondary school teachers participating in English in Action. Dhaka, Bangladesh: EIA. Retrieved July 1, 2012, from http://www.eiabd.com/eia/research

Ekanayake, S. Y., \& Wishart, J. (2015). Integrating mobile phones into teaching and learning: A case study of teacher training through professional development workshops. British Journal of Educational Technology, 46(1), 173-189.

Farrell, T. S. (2016). Surviving the transition shock in the first year of teaching through reflective practice. System, 61, 12-19.

Frohberg, D., Göth, C., \& Schwabe, G. (2009). Mobile learning projects-a critical analysis of the state of the art. Journal of computer assisted learning, 25(4), 307-331.

Hamid, M. O., \& Baldauf, R. B. (2008). Will CLT bail out the bogged down ELT in Bangladesh?. English Today, 24(03), 16-24.

Hamid, M. O., Sussex, R., \& Khan, A. (2009). Private tutoring in English for secondary school students in Bangladesh. Tesol Quarterly, 281-308.

Lee, I. (2007). Preparing pre-service English teachers for reflective practice. ELT journal, 61(4), 321-329.

Li, N., McCormick, R., Power, T., Burton, S., Siddique, A., \& Rahman, S. (2015). Classroom Practices of Primary and Secondary Teachers Participating in English in Action: Third Cohort (2014).

Karim, A., \& Rahman, M. M. (2016). Revisiting the Content-Based Instruction in Language Teaching in relation with CLIL: Implementation and Outcome. International Journal of Applied Linguistics and English Literature, 5(7), 254-264.

Kearney, M., \& Maher, D. (2013). Mobile learning in maths teacher education: Using iPads to support pre-service teachers' professional development. Australian Educational Computing, 27(3), 76-84.

Kearney, M., Schuck, S., Burden, K., \& Aubusson, P. (2012). Viewing mobile learning from a pedagogical perspective. Research in learning technology, 20(1), 14406.

Kukulska-Hulme, A., Sharples, M., Milrad, M., Arnedillo-Sánchez, I., \& Vavoula, G. (2009). Innovation in mobile learning: A European perspective. International Journal of Mobile and Blended Learning (IJMBL), 1(1), 13-35.

Kynäslahti, H. (2003). In search of elements of mobility in the context of education. Mobile learning, 41-48.

Mahruf C. Shohel, M., \& Banks, F. (2012). School-based teachers' professional development through technology-enhanced learning in Bangladesh. Teacher Development, 16(1), 25-42. 
Morris, P., \& Williamson, J. (2000). Teacher education in the Asia-Pacific region: A comparative study. London: Falmer Press.

Newhouse, C. P., Williams, P. J., \& Pearson, J. (2006). Supporting mobile education for pre-service teachers. Australasian Journal of Educational Technology, 22(3).

Nunan, D. (1991). Language teaching methodology: A textbook for teachers. Cambridge: Cambridge University Press.

Obaidul Hamid, M. (2010). Globalisation, English for everyone and English teacher capacity: Language policy discourses and realities in Bangladesh. Current Issues in Language Planning, 11(4), 289-310.

Parsons, D., \& Ryu, H. (2006, April). A framework for assessing the quality of mobile learning. In Proceedings of the International Conference for Process Improvement, Research and Education (pp. 17-27).

Rahman, M., \& Akter, N. (2015). 'ICT-Periodism'in the classroom: Lessons learnt from English in action.

Rahman, M. M., \& Pandian, A. (2016). The gap between research and practice in the field of SLA: The rationale behind it and bridging the gap. Journal of Applied Linguistics and Language Research, 3(3), 162-172.

Schuck, S., Aubusson, P., Kearney, M., \& Burden, K. (2013). Mobilising teacher education: A study of a professional learning community. Teacher Development, 17(1), 1-18.

Seargeant, P., \& Erling, E. J. (2011). The discourse of 'English as a language for international development': Policy assumptions and practical challenges. Dreams and Realities.

Shaheen, R., Walsh, C., Power, T., \& Burton, S. (2013). Assessing the impact of largescale teacher professional development (TPD) in Bangladesh: English in Action (EIA).

Sharples, M., Arnedillo-Sánchez, I., Milrad, M., \& Vavoula, G. (2009). Mobile learning. In Technology-enhanced learning (pp. 233-249). Springer Netherlands.

Shohel, M. M. C., \& Kirkwood, A. (2012). Using technology for enhancing teaching and learning in Bangladesh: challenges and consequences. Learning, Media and Technology, 37(4), 414-428.

Shohel, M. M. C., \& Power, T. (2010). Introducing mobile technology for enhancing teaching and learning in Bangladesh: teacher perspectives. Open learning, 25(3), 201-215.

Shrestha, P. (2011). The potential of mobile technologies for (English) language learning in Nepal. Journal of NELTA, 16(1-2), 107-113.

Shrestha, P. (2012). Teacher professional development using mobile technologies in a large-scale project: Lessons learned from Bangladesh. International Journal of Computer-Assisted Language Learning and Teaching, 2(4), 34-49.

Tasnim, S. (2006). Job Satisfaction among Female Teachers: A study on primary schools in Bangladesh. Master's thesis, The University of Bergen. 
UNESCO. (2008). Supply, retention, preparation and career long professional development of teachers in E9 countries. Paris: UNESCO.

Walsh, C., \& Power, T. (2011). Rethinking development and the use of mobile technologies: Lessons from Bangladesh.

Walsh, C. S., Power, T., Khatoon, M., Biswas, S. K., Paul, A. K., Sarkar, B. C., \& Griffiths, M. (2013). The 'trainer in your pocket': Mobile phones within a teacher continuing professional development program in Bangladesh. Professional Development in Education, 39(2), 186-200.

\section{Turkish Abstract}

\section{ÇED-Bangladeş'teki Öğretmen Eğitim Projesi: Farklılaşmış Perspektiflerden Bir Analiz}

Ingilizce Hareketliliği (ÇED), mobil teknolojiyi eyleminin merkezine yerleştiren, devam etmekte olan bir öğretmen eğitim projesidir.

Bu çalışmada, özellikle mobil öğrenme ve ingilizce hareketliliği başlatan mobil öğrenme arasında karşılaştırmalı bir analiz yapılarak mobil öğrenme bileşenleri ile uyuşan veya eşleşmeyen ölçütleri ortaya çıkartılmış̧tr. Bu çalışma nitel araştırma yöntemi ile desenlenmiş̧tir. Araş̧ırma sonucunda, ÇED bileşenleri, ÇED'in bağlamda olanları gerektirdiği ölçüde, mobil öğrenme ile eşleştiğini ortaya koymuştur. Bu bağlamda birkaç bileşen ve sınıflarında değişiklik yapan öğretmenler içeriğe uygun olmadığı için yoksayılmıştır.

Anahtar Kelimeler: EIA, EFL, öğretmen eğitimi, mobil öğrenme, eleştirel tartışma

\section{French Abstract}

EIA - un Projet d'Éducation de Professeur au Bangladesh: une Analyse de Perspectives Diversifiées

L'anglais dans l'Action (EIA) est un projet d'enseignement de professeur en cours qui situe la technologie mobile du centre de son action. Cette étude, particulièrement, a dessiné une analyse comparative entre l'apprentissage de portable et EIA le portable amorcé apprenant à révéler la mesure avec laquelle il a correspondu ou est allé mal ensemble aux composants d'apprentissage mobile. La méthode qualitative a été utilisée pour conduire cette étude. Le résultat a révélé que les composants d'EIA correspondent au portable apprenant des à la mesure qu'EIA entraîne ceux convenant au contexte. Peu d'éléments ont été semblés absents comme ils sont moins appropriés dans un tel contexte. En plus, les professeurs ont été trouvés apportant des changements de leurs salles de classe.

Mots Clés: EIA, EFL, éducation de professeur, apprentissage de portable, discussion critique

\section{Arabic Abstract}

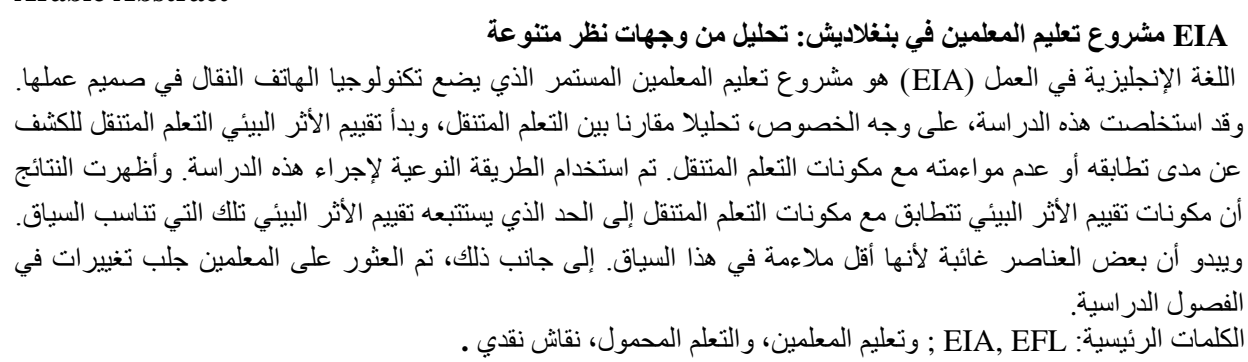




\section{German Abstract \\ EIA- Ein Lehrerausbildungsprojekt in Bangladesch: Eine Analyse aus diversifizierten Perspektiven}

Englisch in Aktion (EIA) ist ein laufendes Lehrerausbildungsprojekt, das die mobile Technologie in den Mittelpunkt ihrer Aktion stellt. Diese Studie zog vor allem eine vergleichende Analyse zwischen dem mobilen Lernen und der UVP initiierte das mobile Lernen, um zu zeigen, inwieweit es mit den Komponenten des mobilen Lernens übereinstimmte oder nicht übereinstimmte. Qualitative Methode wurde verwendet, um diese Studie durchzuführen. Das Ergebnis zeigte, dass die Komponenten der EIA mit dem mobilen Lernen in dem Maße übereinstimmen, in dem die EIA die für den Kontext geeigneten Personen beinhaltet. Nur wenige Elemente schienen abwesend zu sein, da sie in diesem Zusammenhang weniger geeignet sind. Außerdem wurden Lehrer gefunden, die Veränderungen in ihren Klassenzimmern führten.

Schlüsselwörter: EIA, EFL, lehrerausbildung, mobiles lernen, kritische diskussion

\section{Malaysian Abstract \\ EIA- Projek Pendidikan Guru di Bangladesh: Analisis dari Pelbagai Perspektif}

Bahasa Inggeris dalam Tindakan (EIA) adalah projek pendidikan guru yang sedang berjalan yang menempatkan teknologi mudah alih di pusat tindakannya. Kajian ini, terutamanya, menghasilkan analisis perbandingan antara pembelajaran mudah alih dan pembelajaran mudah alih yang dimulakan EIA untuk mendedahkan sejauh mana ia dipadankan atau tidak sesuai dengan komponen pembelajaran mudah alih. Kaedah kualitatif digunakan untuk menjalankan kajian ini. Hasilnya mendedahkan bahawa komponen perlawanan EIA ke pembelajaran mudah alih setakat mana EIA melibatkan mereka yang memadankan konteksnya. Beberapa elemen kelihatan tidak hadir kerana mereka kurang sesuai dalam konteks tersebut. Selain itu, guru-guru didapati membawa perubahan dalam bilik darjah mereka.

Kata Kunci: EIA, EFL, pendidikan guru, pembelajaran mudah alih, perbincangan kritikal

\section{Russian Abstract \\ Английский в Действии-Подготовки Преподавателей Проект в Бангладеш: Анализ с Разных Точек Зрения}

Английский в действии - это постоянный проект педагогического образования, в котором мобильные центры находятся в основе его деятельности. В этом исследовании, в частности, был проведен сравнительный анализ между мобильным обучением и проектом Английский в действии, последний из которых инициировал мобильное обучение, чтобы выявить степень его соответствия или несовместимости с компонентами мобильного обучения. Для проведения этого исследования был использован качественный метод. В результате выяснилось, что компоненты английского в действии соответствуют мобильным учебным программам в той мере, в какой английский в действии влечет за собой те, которые соответствуют контексту. Несколько элементов казались отсутствующими, поскольку они менее подходят такому контексту.

Ключевые Слова: Английский в Действии, Английский как Иностранный, педагогическое образование, мобильное обучение, критическое обсуждение 